\title{
CLINICAL AND CYTOLOGICAL CHARACTERISTICS OF THE GUMS IN CHILDREN OF PRIMARY SCHOOL AGE WITH NORMAL BODY WEIGHT AND OVERWEIGHT
}

DOI: 10.36740/WLek202103108

\author{
Anastasiia V. Onyschenko, Olga V. Sheshukova, Halyna A. Yeroshenko \\ UKRAINIAN MEDICAL STOMATOLOGICAL ACADEMY, POLTAVA, UKRAINE
}

\begin{abstract}
The aim of the research was to study the cellular composition of the gums in children of primary school age with normal body weight and overweight for further use of this data in the early diagnostics of periodontal diseases.

Materials and methods: We examined 81 children aged from 6 to 12 years. Cytological examination of gingival cytograms was performed in all examined children.

Results: Based on the analysis of the quantitative content of epithelial cells in children with normal body weight, their ratio was established, which is determined by the percentage of 0: 6: 94 (parabasal, intermediate, superficial). The obtained data completely coincide with the percentage of the differentiated ratio of epitheliocytes of multilayered squamous epithelium in children with normal body weight with inflammation and without it in the periodontal tissues. Our cytological examinations of gingival scrape smears in overweight children in contrast to the results of the study of epithelial scrape smears in children with normal body weight have some differences. Thus, in the process of calculation, the degree of differentiation of various epitheliocytes determines their percentage as follows - 3: 7: 90 (parabasal, intermediate, superficial) for children with gingivitis, and 2: 5: 93 (parabasal, intermediate, superficial) for children without inflammation in the periodontal tissues.

Conclusions: The obtained results allowed us to conclude that in overweight children, in contrast to children with normal body weight, the number of parabasal cells decreases, and the number of superficial and intermediate cells increases.
\end{abstract}

KEY WORDS: cytogram, children of primary school age, overweight

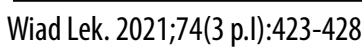

\section{INTRODUCTION}

Inflammatory and dystrophic disorders of the periodontal tissues are so far predominant in the overall structure of pathological processes of the oral cavity in children [1]. It is known that the foci of chronic periodontal infection not only cause contamination of the tissues of the maxillofacial area, but also initiate the emergence of pathological processes in other organs and systems [2]. The results of numerous clinical and epidemiological studies indicate a tendency for an increase in the prevalence of overweight among children and adolescents due to the presence of concomitant somatic diseases $[3,4,5]$. An important role in the development of inflammatory changes in the periodontal tissues in overweight children belongs to a decrease in the overall reactivity of the body [6]. However, the analysis of literature showed the ambiguity of studies on the specific mechanisms of periodontal tissue damage in overweight children and adolescents, especially in the early stages of gingivitis, which is important for both its prevention and treatment. The morphological examination is one of the precise methods to detect pathology in the early stages of development. This method is widely used in the diagnosis of diseases of the oral mucosa and periodontal tissues. Due to its minimally invasive nature and highly informative value, the cytological method has a great advantage in the use of pediatric dentistry [7]. At present, the issues of determining the peculiarities of the cellular composition of the gingival mucosa by the cytological method in primary school children are insufficiently covered, and the comparative analysis of cellular composition in primary school children with normal body weight and overweight has not been performed at all.

\section{THE AIM}

The aim of the research was to study the cellular composition of the gums in children of primary school age with normal body weight and overweight for further use of this data in the early diagnostics of periodontal diseases.

\section{MATERIALS AND METHODS}

We examined 81 children aged from 6 to 12 years, who according to outpatient records did not have a concomitant pathology and underwent a preliminary examination by a pediatrician. The study of anthropometric data and assessment of physical development was conducted in ac- 
Table I. Anthropometric data in the examined children with overweight and normal body weight

\begin{tabular}{|c|c|c|c|c|}
\hline \multirow{2}{*}{ Indicators } & \multicolumn{4}{|c|}{ Groups } \\
\hline & $1 \mathrm{a}$ & $1 \mathrm{~b}$ & $2 a$ & $\mathbf{2 b}$ \\
\hline The number of schoolchildren & 17 & 8 & 40 & 16 \\
\hline Age & $8.75 \pm 0.29$ & $8.44 \pm 0.72$ & $8.38 \pm 0.17$ & $8.86 \pm 0.30$ \\
\hline Height (m) & $1.35 \pm 0.02$ & $1.38 \pm 0.04$ & $1.38 \pm 0.01$ & $1.38 \pm 0.03$ \\
\hline Weight $(\mathrm{kg})$ & $30.76 \pm 1.54$ & $32.96 \pm 2.54$ & $38.90 \pm 1.18^{* * *}$ & $40.41 \pm 2.38^{* * * *}$ \\
\hline $\mathrm{BMI}\left(\mathrm{kg} / \mathrm{m}^{2}\right)$ & $16.61 \pm 0.35$ & $17.05 \pm 0.53$ & $20.37 \pm 0.39^{* * * *}$ & $20.77 \pm 0.61^{* * * *}$ \\
\hline Waist circumference (m) & $0.54 \pm 0.01$ & $0.54 \pm 0.01$ & $0.61 \pm 0.01^{* * *}$ & $0.63 \pm 0.02^{* * * *}$ \\
\hline Thigh circumference (m) & $0.36 \pm 0.01$ & $0.36 \pm 0.01$ & $0.41 \pm 0.01^{* * *}$ & $0.41 \pm 0.02$ \\
\hline Neck circumference (m) & $0.25 \pm 0.01$ & $0.25 \pm 0.01$ & $0.27 \pm 0.003$ & $0.26 \pm 0.01$ \\
\hline Fat fold (mm) & $10.35 \pm 0.69$ & $11.75 \pm 2.81$ & $19.35 \pm 1.17^{* * *}$ & $24.44 \pm 2.49^{* * *}, * * * *$ \\
\hline
\end{tabular}

Note: ${ }^{*}$ the probable difference between groups $1 a-1 b{ }^{* *}$ - between groups $2 a-2 b,{ }^{* * *}$ - between groups $1 a-2 a,{ }^{* * * *}-$ between groups $1 b-2 b, p<0.05$

Table II. The intensity of caries, the hygienic status of the oral cavity and periodontium in children with normal body weight and overweight

\begin{tabular}{ccccc}
\hline \multirow{2}{*}{ Indicators } & \multicolumn{3}{c}{ Groups } \\
\cline { 2 - 5 } & $\mathbf{1 a}$ & $\mathbf{1 b}$ & $\mathbf{2 a}$ & $\mathbf{2 b}$ \\
\hline Dysgnathia & $0.71 \pm 0.12$ & $0.88 \pm 0.13$ & $0.48 \pm 0.78$ & $0.43 \pm 0.13^{* * * *}$ \\
\hline cf & $1.18 \pm 0.43$ & $0.5 \pm 0.5$ & $1.85 \pm 0.35$ & $1.13 \pm 0.52$ \\
\hline CFR & $0.29 \pm 0.14$ & $0.5 \pm 0.33$ & $0.18 \pm 0.09$ & $0.25 \pm 0.25$ \\
\hline cf + CFR & $1.47 \pm 0.44$ & $1 \pm 0.53$ & $2.03 \pm 0.36$ & $1.25 \pm 0.54$ \\
\hline OHI, point & $1.64 \pm 0.08$ & $1.75 \pm 0.06$ & $1.53 \pm 0.06$ & $1.58 \pm 0.08^{* * * *}$ \\
\hline PMA, \% & 0 & $25 \pm 0.03$ & 0 & $30 \pm 0.03^{* * * *}$ \\
\hline
\end{tabular}

Note: ${ }^{*}$ the probable difference between groups $1 a-1 b,{ }^{* *}-$ between groups $2 a-2 b,{ }^{* * *}-$ between groups $1 a-2 a,{ }^{* * *}-$ between groups $1 b-2 b, p<0.05$

Table III. Cytological characteristics of scrape smears in children aged 6-12 years (in the field of view)

\begin{tabular}{|c|c|c|c|c|c|c|c|c|}
\hline \multirow{3}{*}{ Indicators } & \multicolumn{8}{|c|}{ Groups } \\
\hline & \multicolumn{2}{|l|}{$1 \mathrm{a}$} & \multicolumn{2}{|c|}{$1 b$} & \multicolumn{2}{|c|}{$2 a$} & \multicolumn{2}{|l|}{$2 \mathbf{b}$} \\
\hline & $\begin{array}{l}\text { Cells in the } \\
\text { field of view }\end{array}$ & $\%$ & $\begin{array}{l}\text { Cells in the } \\
\text { field of view }\end{array}$ & $\%$ & $\begin{array}{l}\text { Cells in the } \\
\text { field of view }\end{array}$ & $\%$ & $\begin{array}{l}\text { Cells in the } \\
\text { field of view }\end{array}$ & $\%$ \\
\hline Basal & 0 & & 0 & & 0 & & 0 & \\
\hline Parabasal & $0.13 \pm 0.09$ & $0.13 \%$ & $0.38 \pm 0.15^{*}$ & $0.37 \%$ & $2.25 \pm 0.49^{* * *}$ & $2.21 \%$ & $3 \pm 0.01^{* *}, * * * *$ & $2.93 \%$ \\
\hline Intermediate & $6.31 \pm 0.32$ & $6.31 \%$ & $6.58 \pm 0.38$ & $6.58 \%$ & $5 \pm 0.53^{* * *}$ & $4.92 \%$ & $7.41 \pm 0.51^{* *}, * * * *$ & $7.24 \%$ \\
\hline Superficial & $93.56 \pm 0.79$ & $93.56 \%$ & $93.05 \pm 0.52$ & $93.05 \%$ & $94.38 \pm 1.25$ & $91.88 \%$ & $91.94 \pm 0.42^{* * *}, * * * *$ & $89.83 \%$ \\
\hline
\end{tabular}

cordance with the Order of the Ministry of Public Health of Ukraine as of 13.09. 2013 No. 802 "Criteria for assessing the physical development of school-age children" [8] for further formation of research groups.

Clinical dental examination was performed according to the WHO method, 2013 [9]. The hygienic condition of the oral cavity was assessed using the simplified Green-Vermillion hygienic index [10]. To detect the inflammatory process and assess its intensity in the periodontal tissues, the PMA index was determined. [11].

Cytological study of gingival cytograms was performed in all examined children. Smears were obtained by scraping the mucous membrane of the gums, rotating the working part of the spatula, the resulting material was applied to a degreased glass slide. Drying of the smears was performed by the dry fixation method at room temperature under conditions of open air access. Smears were placed in a container for glasses and lowered into a special reservoir with May-Grünwald fixative stain [12]. The smears were fixed for 5 minutes, washed with water and laid out in a special tripod for drying. Cytogram analysis was performed using a Biorex-3 BM-500T microscope with a DCM-900 digital photomultiplier with programs adapted for the study data, using a magnification of 1000 . Quantitative parameters were determined by counting cellular elements in 5 fields of view, recording the amount in absolute numbers, and determining averages using Excel software [13]. 


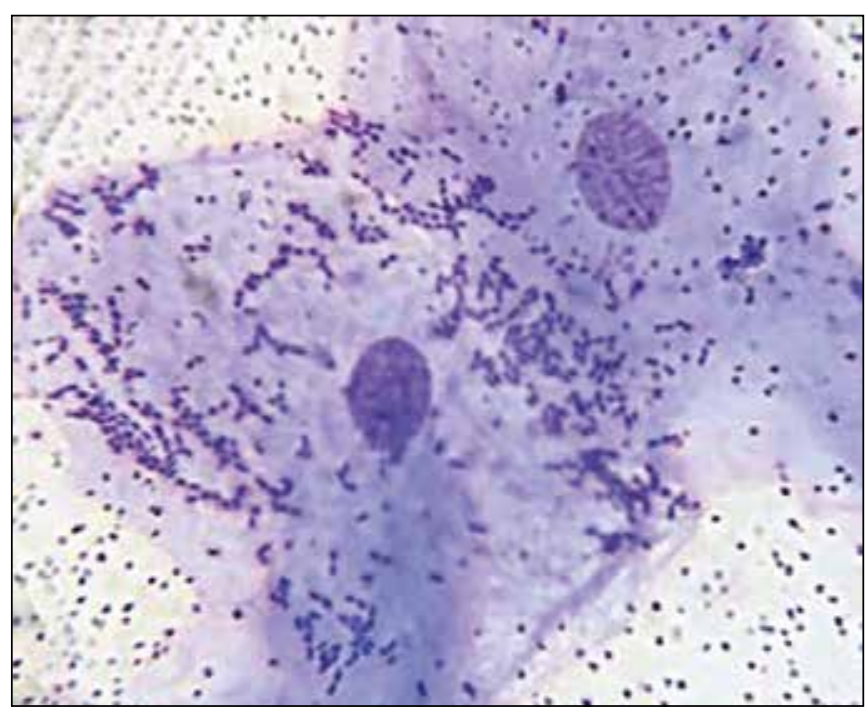

Fig. 1a. Intermediate cells in the cytogram of the gums in a child with normal body weight, without inflammation and with a subcompensated form of caries. May-Grünwald's stain. Magn.: obj. x 100, eyepiece x 10.

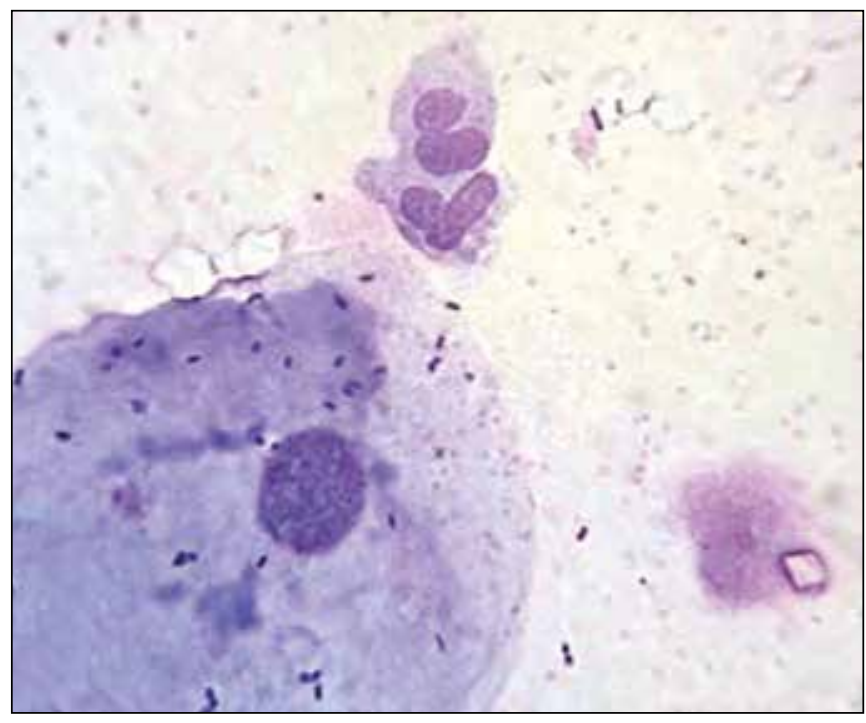

Fig. 2a. Superficial cells and segmental leukocytes in the cytogram of the gums in a child with normal body weight, with inflammation in the periodontal tissues. May-Grünwald's stain. Magn.: obj. x 100, eyepiece $x 10$.

\section{RESULTS AND DISCUSSION}

The conducted examination of children with overweight and normal body weight allowed us to divide the two study groups into subgroups ( $1 \mathrm{a}, 1 \mathrm{~b}$ and $2 \mathrm{a}, 2 \mathrm{~b}$ ). The first group consisted of 25 subjects whose general development and weight corresponded to the age norm, 8 of them had the phenomena of catarrhal gingivitis. 56 children were overweight, 16 of them showed signs of periodontal inflammation, and 40 children had clinically healthy gums.

After analyzing the main indicators of anthropometric studies, we concluded that the height in all studied groups corresponds to the age norm and ranges from $1.33 \mathrm{~kg} / \mathrm{m}^{2}$ to $1.42 \mathrm{~kg} / \mathrm{m}^{2}$. BMI $\left(\mathrm{kg} / \mathrm{m}^{2}\right)$ differs significantly due to

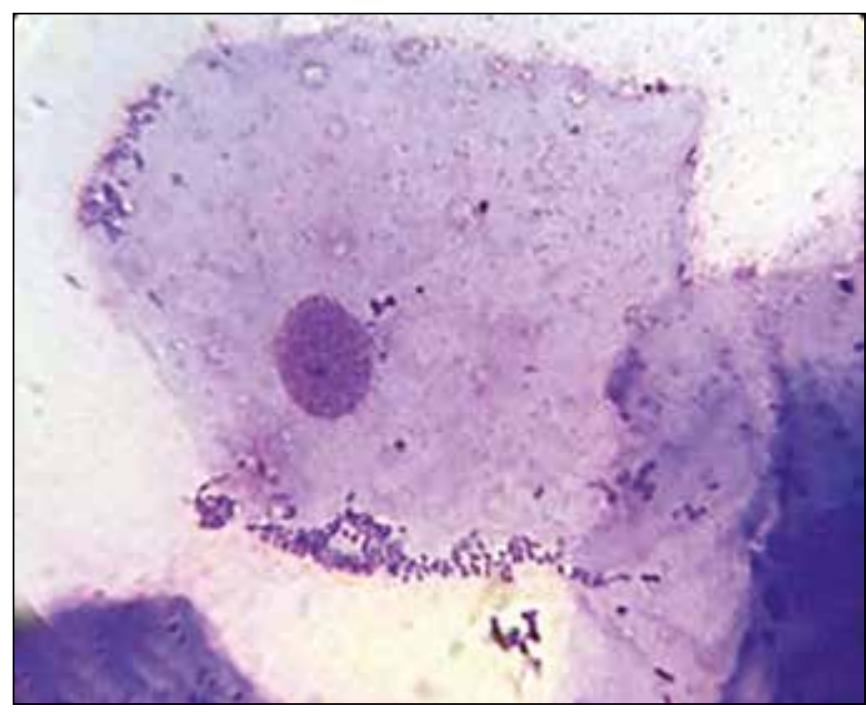

Fig. 1b. A superficial maturing cell in the cytogram of the gums in a child with normal body weight, without inflammation. May-Grünwald's stain. Magn.: obj. x 100, eyepiece x 10 .

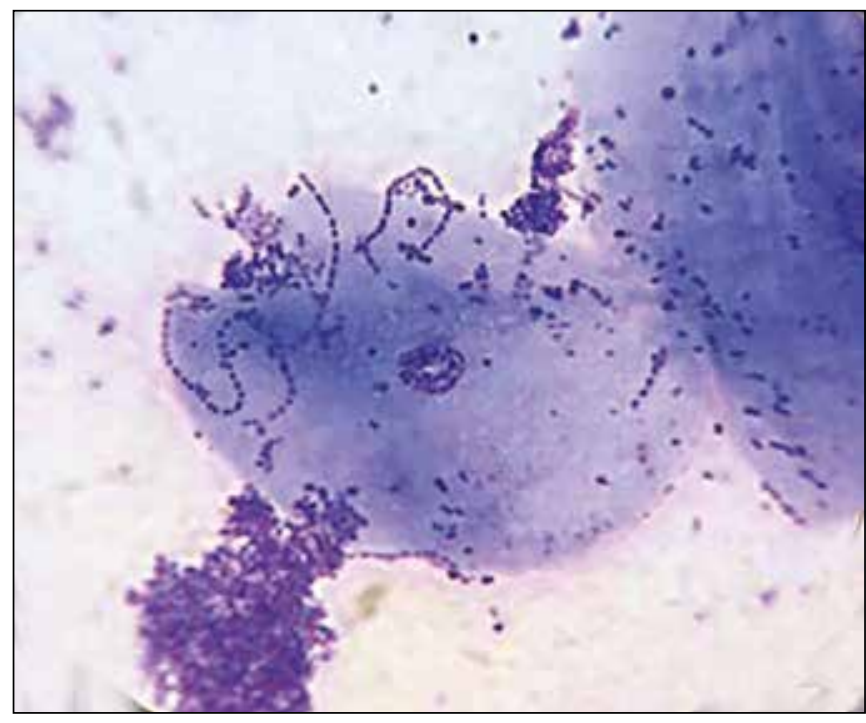

Fig. 2b. Contamination of microorganisms in the cytogram of the gums in a child with normal body weight, with inflammation in the periodontal tissues and a compensated form of caries. May-Grünwald's stain. Magn.: obj. x 100, eyepiece x 10 .

body weight indicated, which is interpreted according to the WHO centile tables.

The ratio of waist circumference $(\mathrm{m})$ to thigh circumference $(\mathrm{m})$ and thickness of the fat fold are reliable for diagnosis. That is, in the future one can use the WC / TC ratio and the quantitative value of the fat fold for the diagnosis of obesity in children of primary school age (Table I).

The study of caries intensity showed that in the examined children with normal body weight the index of $\mathrm{cf}+\mathrm{CFR}$ is $1.47 \pm 0.44$ teeth for children without gingivitis and $1 \pm$ 0.53 teeth for children with gingivitis. In overweight children, this figure was higher $(2.03 \pm 0.36$ and $1.25 \pm 0.54$, respectively, $\mathrm{p}<0.05)$. The prevalence of caries in children 


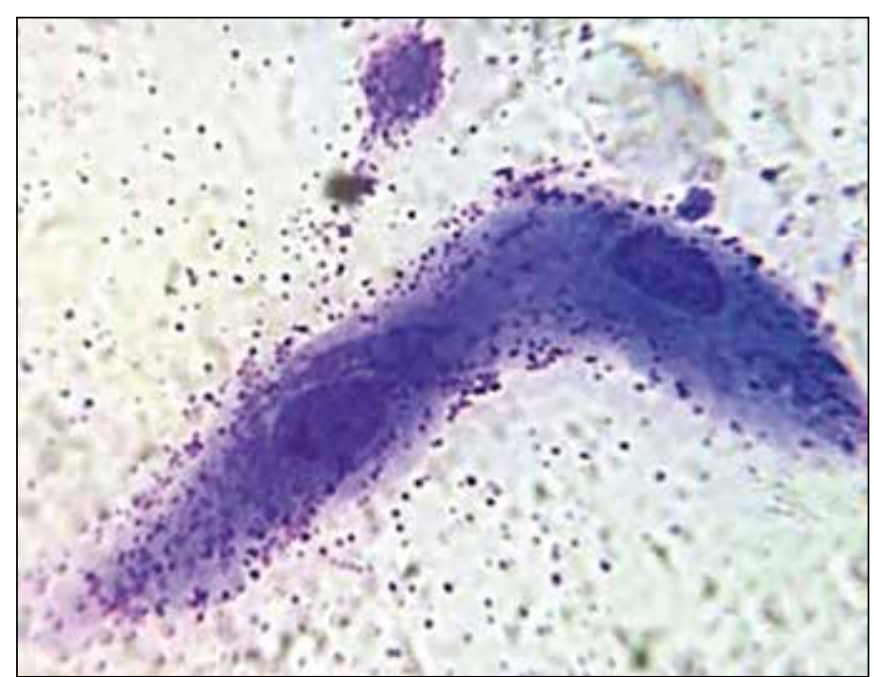

Fig. 3a. Parabasal cells in the cytogram of the gums of an overweight child without inflammation with a compensated form of caries. May-Grünwald's stain. Magn.: obj. x 100, eyepiece x 10.

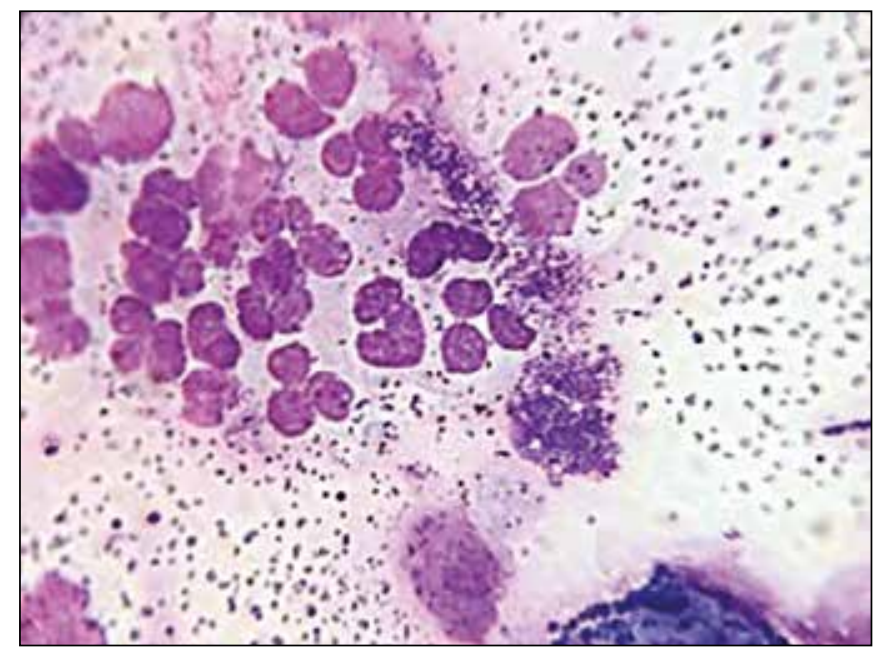

Fig. 4a. Leukocyte, lymphocyte, mycelium of fungi in the cytogram of the mucous membrane of the gums in an overweight child with inflammation in the periodontal tissues. May-Grünwald's stain. Magn.: obj. $x$ 100 , eyepiece x 10 .

with normal body weight was $53 \%$ and $38 \%$, respectively, and in the group of overweight children, it was slightly higher - about $60 \%$ and $44 \%$, respectively (Table II).

The oral hygiene index in children with normal body weight and overweight corresponded to satisfactory hygiene regardless of the degree of inflammation in the periodontal tissues. Children with normal body weight, diagnosed with gingivitis, had worse hygiene, which was on the verge of satisfactory and poor hygiene as compared to the group of overweight children with gingivitis.

To assess the intensity of the inflammatory process in the periodontal tissues of children in the study groups, the data of the PMA index were analyzed. It was found that in children with normal body weight, the PMA index was $25 \pm 0.5 \%$, while in overweight children the index data

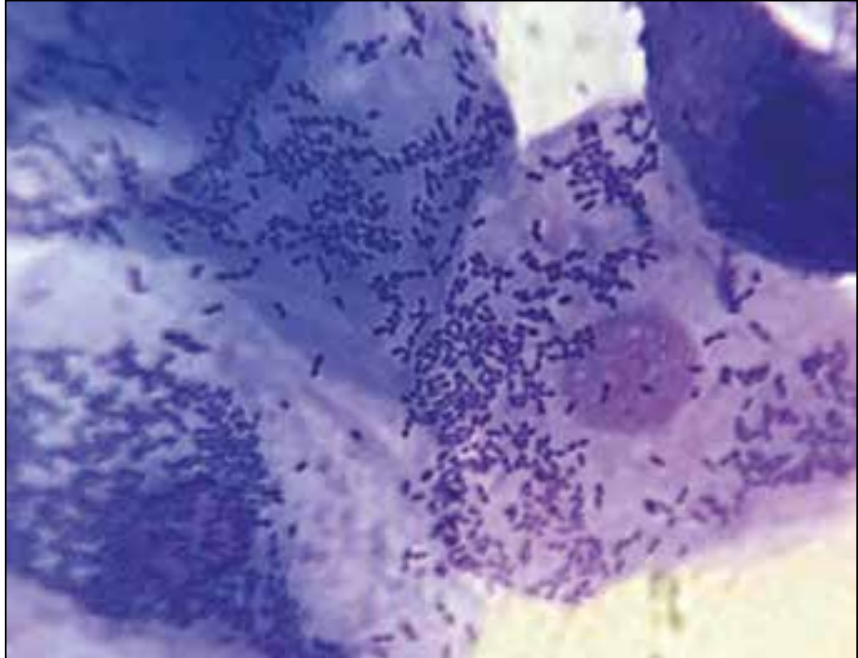

Fig. 3b. Contamination of microorganisms, karyopyknosis in superficial cells in the cytogram of the gums of an overweight child with inflammation in the periodontal tissues and a compensated form of caries. May-Grünwald's stain. Magn.: obj. x 100, eyepiece x 10.

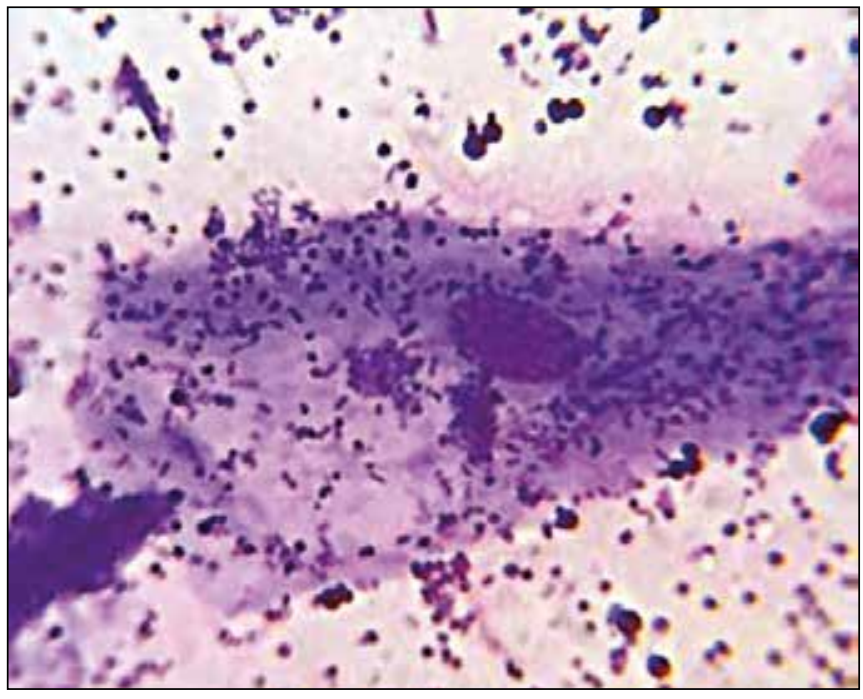

Fig. $\mathbf{4 b}$. The navicular cell in the cytogram of the gums of an overweight child with inflammation in the periodontal tissues. May-Grünwald's stain. Magn.: obj. x 100, eyepiece x 10 .

were higher and amounted to $30 \pm 0.03 \%$, which was also characterized as moderate gingivitis.

In the epithelium of the mucous membrane of the human gums, there are defined 4 classes of cells - basal, parabasal, intermediate and superficial. In cytograms from the gingival mucosa of children, parabasal epitheliocytes are almost absent, which is due to their functional features [14]. According to the results of cytological studies of the cellular composition of the cytograms in the gums of school-age children, we found that they were dominated by superficial cells (Table III).

In children of group $1 \mathrm{~b}$, the number of parabasal cells was slightly greater than in 1a, though very small. We did not find any other quantitative differences in the cytograms of children with normal body weight. 
The average number of intermediate cells in groups la and $1 \mathrm{~b}$ had no significant difference. In children with normal body weight, the intermediate cells in the cytograms had a polygonal shape, a centrally located oval nucleus with structured chromatin. There was weak contamination of microorganisms on the cell surface (Fig. 1a). Superficial epitheliocytes in the cytograms of the gums in children of group la were smaller in size than intermediate cells, characterized by a rounded shape and an uneven contour of the plasmolemma. The nuclei of superficial epitheliocytes were located eccentrically in the cytoplasm and were hyperchromic (Fig. 2b).

For children with normal body weight and inflammation in the periodontal tissues, the cytograms were characterized by the presence of epitheliocytes, mainly of the superficial layer, in the scrape smears from the gingival surface. Their cytoplasm was weakly basophilic, lumps of keratohyalin were observed. Round nuclei were found at different stages of karyopyknosis. This group of children was characterized by the presence of segmental leukocytes and single lymphocytes in the cytograms (Fig. 2a).

The greater intensity of contamination of microorganisms on the surface of superficial epitheliocytes attracted our attention (Fig. 2b). This cytological presentation is observed in chronic gingivitis and in exacerbation of chronic gingivitis of lesser intensity.

Cytomorphological studies of scrape smears from the gingival mucosa revealed that in the group of overweight children without inflammation of the periodontal tissues, the number of parabasal was significantly greater than in groups $1 \mathrm{a}$ and $1 \mathrm{~b}$, whereas the intermediate ones were significantly fewer $(\mathrm{p}<0.05)$. The number of superficial cells was relatively larger, but no statistical difference was found (see Table 3).

In the group of overweight children with inflammation of the periodontal tissues, the average number in the field of view of parabasal cells (Fig. 3a) was significantly higher by $33 \%$, and the number of the intermediate ones - by $48.2 \%$ than in the group without inflammation. The average number of superficial cells in group $2 \mathrm{~b}$ was significantly lower by $2.59 \%$ (see Table 3 ).

We detected epitheliocytes with the signs of karyolysis, epithelial cells with destroyed nuclei, and epitheliocytes containing nuclei with unevenly distributed fine-grained chromatin. The greatest degree of manifestation of contamination of microbial flora attracted our attention, sometimes microorganisms covered the entire surface of cells (Fig. 3b).

In addition to epithelial cells, lymphocytes and neutrophilic granulocytes were visualized in the cytograms of overweight children, and the number in the field of view was higher in children with inflammation of the periodontal tissues (Fig. 4a).

It was found that in the group of overweight children with inflammation in the periodontal tissues, there was a significantly higher number of epitheliocytes with degenerative changes (Fig. $4 \mathrm{~b}$ ) as compared to the number of such cells in the group of children without inflammation of the periodontal tissues. It should be noted that degenerative changes in the squamous epithelial cells in inflammatory diseases can lead to cell death.

Cytological diagnosis allowed us to evaluate the obtained cytological presentation of scrapes from the oral mucosa, represented by multilayered squamous epithelium without keratinization, in the intact periodontium and in the occurrence and development of inflammatory changes therein.

The study of cells of the multilayered squamous epithelium of the oral mucosa in overweight children proved the presence of parabasal, intermediate and superficial cells, but with a predominance of intermediate and superficial type of cells.

In the group of children with inflammation in the epithelial layer, neutrophilic leukocytes and small lymphocytes are found. Single lymphocytes have no significant diagnostic value, but an increase in their number in cytological specimens over $5 \%$ indicates the involvement of the body's immune system and the transition from acute to chronic inflammatory reaction [6]. Monocytes in smears are very rare.

Most often in the smears of children with normal body weight, there were individual segmental neutrophilic granulocytes (normal, sometimes degeneratively altered - with a hypersegmented nucleus, without intersections between the segments that have lost specific granularity). In children with inflammation in the periodontal tissues, the number of leukocytes in the cytograms was higher. Thus, we can assume that the increased content of neutrophils in the epithelium and on its surface is an additional protective antimicrobial mechanism in areas of the mucous membrane that are not protected by the stratum corneum.

The literature data demonstrate that the appearance of neutrophilic granulocytes in cytological specimens in the amount equal to or exceeding $10 \%$ of the total number of cells (especially morphologically unaltered) indicates an acute inflammatory process in the oral cavity [13].

Based on the analysis of the cellular composition of cytograms in children with normal body weight without inflammation and with inflammation of the periodontal tissues, their ratio was 0: 6: 94 (parabasal, intermediate, superficial).

Our cytological examinations of gingival scrape smears in overweight children have some differences as compared to the results of the study of epithelial scrape smears in children with normal body weight. Hence, in the process of calculation, the degree of differentiation of various epitheliocytes determines their percentage as follows: $2: 5: 93$ in children without inflammation of periodontal tissues and 3: 7: 90 in children with inflammation.

In overweight children, in contrast to children with normal body weight, the number of parabasal cells increases, the number of superficial cells decreases and the number of intermediate cells increases.

Obviously, such changes in cytological components are related to the characteristics and condition of the entire organism. This is why parabasal cells appear, which are smaller than intermediate cells. In parabasal cells, the nucleus is not clearly contoured, surrounded by tonofibrillar structures. 


\section{CONCLUSIONS}

The cytological presentation is an important indicator and the assessment of cellular composition allows us to obtain information that enables determining the presence of preconditions for inflammation at the pre-nosological level for the prevention and prophylaxis of periodontal disease in primary school children.

\section{REFERENCES}

1. Sanz M., Herrera D., Kebschull M., et al; EFP Workshop participants and methodological consultants. Treatment of periodontitis - The EFP S3level clinical practice guideline. J Clin Periodontol. 2020;47(S22):4-60. https://doi.org/10.1111/jcpe.13290

2. Peres K.G, ThomsonW.M., Chaffee B.W., et al. Rugg-Gunn Oral Health Birth Cohort Studies: Achievements, Challenges, and Potential Journal of Dental Research, 17 Jul 2020. https://doi. org/10.1177/0022034520942208.

3. Bezwushko Ye.V., Zhuhina L.F., Narykova A.A. et al. Porivnialna ocinka stomatologicznogo zdorovia ditwj shkilnogo viku za Yevropejskymy indykatoramy zdorovia porozhnyny rota. Nowyny stomatologii. 2013;3:76-80.

4. Ogijenko V.P. Statystyczni dani po poshyrenniu ozhyrinnia v Ukraini i sviti. [Elektronnyi resurs] : http://medstat.gov.ua/ukr

5. Sheshukova 0.V., Onyshchenko A.V. vmist interleikinu - 10 u rotovii ridyni ditej molodshogo shkilnogo viku z normalnoju ta nadmirnoiu masoiu tila. Visnyk problem Biologii i medycyny. 2020; 157 (3): 374- 377.

6. Zahajnova N.N. Koreliacyonnaia swiaz mezhdu pokazateliami intensivnosti karijesa zubov, sostojanijem tkaniej paradonta i gigijeny polosti rta u detej. Visnyk stomatologii. 2017;2:51-52.

7. Sheshukova 0.V., Yeroshenko G.A., Trufanova V.P. et al. Method of preclinical determination of probability of inflammation of periodontal tissues in children. Ukraine patent 130471. 2018 June 4.

8. Pro zatverdzhennya Kryteriyiv otsinky fizychnoho rozvytku ditey shkil'noho viku [On approval of Criteria for assessment of physical development of school children]. 2013. Available from:http:// zakon.rada.gov.ua/laws/show/z1694-13.

9. World Health Organization. Oral Health Surveys Basic Methods, 5th Ed. - Geneva : WH0, 2013, p.125

10. Homenko L.O. et al. Terapevtyczna stomatologiia dytiachogo viku. Karijes zubiv ta jogo uskladnennia. Kyiv. Knyga Plus, 2014, p.132.

11. Kostura V.L. Indeksna ocinka stanu tkanyn paradonta u ditej z nadmirnoiu masoiu tila. Visnyk problem biologii ta medycyny. 2018; 1 (142):360-363.
12. Gasyuk N.V., Yeroshenko G.A. Osobennosti kletochnogo sostava desen pri generalizovannom parodontite. [Feature of cellular composition of the gums in generalized periodontitis.] Svit meditsini I blologyi. 2015; 1(48): 17-2.

13. Lapach S.N., Chubenko A.V., Babich P.N. Statisticheskie metodyi v medikobiologicheskih issledovaniyah s ispolzovaniem Exel. [Statistical data in biomedical research using Exel.] Kiev; 2000.320 p.

14. Sheshukova 0.V., et al. Cytologichna kharakterystyka klitynnogo skladu slyzovoi obolonky jasen u ditej shkilnogo viku. Aktualni problemy suchasnoi medycyny: Visnyk Ukrainskoi medycznoi stomatologichnoi akademii. 2019;2 (66):146-150.

This study is a part of the research projects No.0117U005251 "Development of methods for treatment of inflammatory pathology of the maxillofacial area aimed at polarization of macrophages subpopulations», and No.0117U004683 «Study of pathogenetic mechanisms of the most widespread children's diseases, optimization of their diagnostics and treatment».

\section{ORCID and contributionship:}

Anastasiia V. Onyschenko: 0000-0003-0971-3149 ${ }^{\text {B,C,D }}$

Olga V. Sheshukova: 0000-0002-4739-4890 A,B,F

Halyna A. Yeroshenko: ${ }^{E, F}$

\section{Conflict of interest:}

The Authors declare no conflict of interest

\section{CORRESPONDING AUTHOR Anastasiia V. Onyschenko \\ Ukrainian Medical Stomatological Academy \\ 40 Hrusheva Str, 36000, Poltava, Ukraine \\ tel: +380677982042 \\ e-mail: veretilnik@meta.ua}

Received: 22.10 .2020

Accepted: 23.02 .2021

A - Work concept and design, B - Data collection and analysis, C - Responsibility for statistical analysis, D-Writing the article, $\mathbf{E}$-Critical review, $\mathbf{F}$ - Final approval of the article 